Article

\title{
Saint Paul: A Revolutionary Subject
}

Delfo C. Canceran

\begin{abstract}
This paper highlights Badiouian philosophy of the subject by making use of the model of Paulinian vocation. The Badiouian subject is not defined prior to its vocation but is made a subject by the call to revolutionary movement. In the Paulinian model, Paul is called by the risen Jesus, and Paul pursued that call by building a community defined by faith and not by law. The universal community is marked by indifference to the differences of its members. The Badiouian contribution to the social movement is clearly the presentation of the vocation of Saint Paul in building a new humanity based on equality and inclusiveness.
\end{abstract}

Keywords: Badiou, Event, subject, truth

I read Paul as a text about a new and provocative conception of truth and, more profoundly, about the general conditions for a new truth... I read Paul as a human creation in the field of the question of truth. ${ }^{1}$

- Alain Badiou

$\mathrm{B}$ adiou is considered as a philosopher of the new. ${ }^{2}$ However, some skeptics ask if there is something new under the sun? There seems to be preponderance to the old and the same expressed in this skepticism. Of course, we are not speaking of literal things under the sun, but this suggests that the sun exposes everything to visibility and clarity so that everything becomes evident in our sight or vision. However, in this world where not everything is clear and obvious, we need to inquire into it or wonder about it. Moreover, conservatives suspect the new because it upsets the things as usual or the order of things in the world. Tradition, as the reproduction of the same, seems to be the natural and sacrosanct thing, thus,

${ }^{1}$ Adam S. Miller and Alain Badiou, "Universal Truths and the Question of Religion: An Interview with Alain Badiou," in Journal of Philosophy and Scripture, 3:1 (2005).

2 See Ed Pluth, Badiou: A Philosophy of the New, (Cambridge: Polity Press, 2010).

(C) 2020 Delfo C. Canceran

https://www.kritike.org/journal/issue 27/canceran december2020.pdf

ISSN 1908-7330 
the new seems aberrant or fake. Unable to handle the new, the conservatives discard or discount it, and stick with or adhere to the old tradition for complacency and security. ${ }^{3}$

To demonstrate his penchant of the new, Badiou writes about the life of Paul, not as a theological piece or a hermeneutical treatise that endeavors to interpret his letters, but a philosophical and a revolutionary enterprise that concretizes this new in the event: the resurrection of Jesus. ${ }^{4}$ For Badiou, Paul exemplifies the militant or activist figure of the event that enables the latter to embark into a new endeavor and spread Christianity. Paul demonstrates the faithful subject to the event. This Paulinian model of revolutionary spirit is badly needed in this time of dearth of leaders and fatigue to activism in some militant movements. Badiou shows that the conversion or vocation of Paul leads him to embrace militant engagement in the world. This engagement requires fidelity to the event that enables him to persevere or persist. This new experience of Paul makes him a relevant figure of revolutionary movement. ${ }^{5}$

\section{Vision of Saint Paul}

Badiou presents the life of Paul, the Apostle as recorded mostly in his biblical writings, to exemplify his understanding of the event and activism that provides a revolutionary figure in our history. ${ }^{6}$ In the interview, Badiou states that he reads Paul not as a sacred text or a hermeneutic task, but as a political figure with revolutionary passion. Moved by that event in a vision, Paul is impelled by a new truth that questions and transforms the world. In particular, Paul's conversion or vocation transformed him into a new subject of revolutionary movement in the making of the church. Paul consistently proclaims the resurrection of Jesus Christ as the inspiration of this new movement. Paul began as a persecutor of the people who followed the way of Jesus Christ but in his Damascus experience, he was altered. That new experience compelled him to pursue a different path and enter into a missionary work. In the Acts of the Apostles, it is written:

3 See Thomas S. Kuhn, The Structure of Scientific Revolution (Chicago: Chicago University Press, 1962).

${ }^{4}$ Alain Badiou, Saint Paul: The Foundation of Universalism, trans. by Ray Brassier (Stanford: Stanford University Press, 2003).

${ }^{5}$ There is a question on the correct description of Paul's experience in Damascus when the risen Jesus Christ appeared and conversed to him. For some, this particular experience is not a conversion but a vocation because he is called by Jesus Christ to become an apostle and member of the church. See Stanley E. Porter, "Paul as Jew, Greek and Roman: An Introduction," in Paul: Jew, Greek and Roman, ed. by Stanley E. Porter, (Leiden: Brill, 2008).

${ }^{6}$ Badiou, Saint Paul, 2.

(C) 2020 Delfo C. Canceran

https://www.kritike.org/journal/issue 27/canceran december2020.pdf

ISSN 1908-7330

(c) $\mathrm{BY}-\mathrm{NC}-\mathrm{ND}$ 
Now as he [Saul/Paul] was going along and approaching Damascus, suddenly a light from heaven flashed around him. He fell to the ground and heard a voice saying to him, "Saul, Saul, why do you persecute me?" He asked, "Who are you, Lord?" The reply came, "I am Jesus, whom you are persecuting. But get up and enter the city, and you will be told what you are to do." The men who were traveling with him stood speechless because they heard the voice but saw no one. Saul got up from the ground, and though his eyes were open, he could see nothing; so, they led him by the hand and brought him into Damascus. For three days he was without sight, and neither ate nor drank (Acts 9:4-9 NRSV).

Paul was bent on chasing the Christians who, when arrested, were ruthlessly persecuted. He persecuted them because they proclaimed that the Messiah had already come and, being a Pharisee himself, this proclamation threatened the authority of the law. ${ }^{7}$ In that passage, Paul was planning to hunt more Christians in Jerusalem. But on his way to Damascus, a light flashed on him and blinded him. That encounter between stunned Paul and the risen Jesus opened a new present different from his previous life. He was seized by that vision that propelled him to embark on a new path. This visionary encounter with the risen Jesus called him to a mission. Ordinarily, conversion is a long and slow process of transformation. In this particular case, this encounter seems to suggest that Paul was converted easily, and led to a new life. We may say that, by the grace of God, he was quickly converted. In his letters, grace was prominent in his teachings, relentlessly defending it against finding favor by mere human effort and achievement. ${ }^{8}$

However, we can also say that he can easily shift to being a Christian due to his hybrid identity: belonged to a Diaspora Jew, gained Greek education, and claimed Roman citizenship rolled into a unique personality. These three worlds-Jewish, Greek, and Roman-provided him an advantage in his preparation and knowledge, and set him to embrace his new vocation or call becoming the apostle to the Gentiles. Thus, this multiple identity allowed him to be receptive and open to new experience and fresh venture. For example, being a Pharisee, he believed in the resurrection of the dead and, when the risen Jesus appeared to him, he was easily convinced of

\footnotetext{
${ }^{7}$ Jerome Murphy-O'Connor, Paul: His Story (Oxford: Oxford University Press, 2004),

23.

${ }^{8}$ Klaus Hacker, "Paul's Life," in The Cambridge Companion to Saint Paul, ed. by James D.G Dunn (Cambridge: Cambridge University Press, 2003), 24.
}

(c) 2020 Delfo C. Canceran

https://www.kritike.org/journal/issue 27/canceran december2020.pdf

ISSN 1908-7330

(cc) BY-NC-ND 
that vision. That identity facilitated his shift to being a Christian by proclaiming the resurrected Jesus. ${ }^{9}$

After his conversion, Paul has embraced a new way of life. He takes the radical view of faith in fidelity to that event. This shift shows the break in the life of Paul, first as a persecutor of Christians then, as apostle to the Gentiles. This break is laden with mystery. Due to his preference for the new, Badiou subscribes to the historical break since he posits the necessity of an event that rips or ruptures the continuity of life. That event must be very significant because it impacts the life of the person. Thus, the model of Paul answers the search for a radical figure worth emulating in our own time. Paul's vision on the road to Damascus equipped him with an entirely new perspective, deeply rooted in that encounter with the risen Jesus. This new perspective summons him to be an apostle by proclaiming the resurrection, which inaugurates a new world where justice and peace reign among the people. ${ }^{10}$

\section{Event of Truth}

When Badiou speaks of the event, he does not refer to the flat and typical happening around us, but rather, to the singular and transformative episode that befalls us in the world. ${ }^{11}$ An event is not just an occurrence that befalls a person, but an experience that transforms the person. Event is the sudden irruption of the new the effect of which is compelling and enduring to the person. The event that happened in Damascus transformed the life of Paul. This event cannot be captured by the available knowledge but, seeks a new language that articulates it. ${ }^{12}$ Moreover, that event brings forth truth by transforming the world. The truth interrupts or breaks the world as usual. Equipped with this truth, Paul persistently challenges the order of things. In fact, this event is a driving force that alters the world. By contesting the reigning present, he insists on this new order that should replace and govern the new-found community. This new order crumbles the wall that separates the members of the community. ${ }^{13}$ In his letter to the Galatians, Paul spoke of an inclusive community that overcomes division.

\footnotetext{
${ }^{9}$ See Richard Wallace and Wynne Williams, The Three Worlds of Paul of Tarsus (London: Routledge, 1998).

${ }^{10}$ N.T. Wright, What Saint Paul Really Said: Was Paul of Tarsus the Real Founder of Christianity? (Michigan: William B. Eerdmans Publishing Company, 1997), 37.

${ }^{11}$ Badiou provides the example of this event in the historic May 1968 revolution in France that significantly changed various institutions in the country like the workplaces, universities, arts, and so on. See Alain Badiou, The Rebirth of History: Times of Riots and Uprisings, trans. by Gregory Elliott, (London: Verso, 2012).

${ }^{12}$ Christopher Norris, Badiou's Being and Event (London: Continuum, 2009), 9.

${ }^{13}$ Badiou, Saint Paul, 108. 
As many of you as were baptized into Christ have clothed yourselves with Christ. There is no longer Jew or Greek, there is no longer slave or free, there is no longer male and female; for all of you are one in Christ Jesus (Galatians 3:26-28 NRSV).

The event of the resurrection of Jesus surmounts or obliterates all divisions such as ethnicity, status or gender. Faith in Christ is the sole requirement in this new community of believers. Badiou carefully establishes the singularity of Paul's position in the controversy of difference and opposition between the Jewish ethnic election (and law), and the Greek love of logic (philosophy). The event neither needs selection nor logic because it overcomes or transgresses it. In Christ, through baptism, the difference or opposition of traditions that mark people off in the community disappears because there is a new standard established by faith. ${ }^{14}$ The event challenges this status that sets the Jews and the Greeks apart. In the confrontation between Paul and Peter on matters of common meals, we see Paul opposing Peter separating himself from the common meal, and dividing the community composed of Jewish Christians, and Gentile Christians.

But when Cephas [Peter] came to Antioch, I opposed him to his face, because he stood self-condemned; for until certain people came from James, he used to eat with the Gentiles. But after they came, he drew back and kept himself separate for fear of the circumcision faction. And the other Jews joined him in this hypocrisy, so that even Barnabas was led astray by their hypocrisy. But when I saw that they were not acting consistently with the truth of the gospel, I said to Cephas before them all, 'If you, though a Jew, live like a Gentile and not like a Jew, how can you compel the Gentiles to live like Jews?'(Galatians 2:11-14 NRSV).

Paul is cognizant of the community consisting of Jews and Greeks. He sticks to the new order by respecting their differences without imposing any privileged practice. He recognizes and accepts these differences that mark the members. This passage diverges from the amicable agreement forged in Jerusalem and leads to a confrontation between them. For Paul, Peter's separation violated the agreement of the unity of the community. By

${ }^{14}$ Daniel Boyarin, A Radical Jew: Paul and the Politics of Identity (Berkley: University of California Press, 1994), p. 16. 
Peter's gesture, the Gentiles are rejected from table fellowship with the Jews and, by implication, to be admitted to the table, the Gentiles need to renounce their Greek custom, and by force, assume the Jewish custom. That confrontation on table fellowship shows that Paul is persistent on the demand for inclusion that would govern the community, and overturns that division. The new agreement of respect and inclusion in the emerging community exceeds the evident difference between the Jews and the Greeks. The difference between the two is superseded by a new truth by transcending such difference. This transcendence does not demolish their customs and practices but insists on an indifference to this difference. Truth procedure can only offer indifference to the differences that exist between the Jews and the Gentiles in forming an inclusive church.

In Badiou's view, the event is closely linked with truth. Badiou reconceptualizes truth neither as a correspondence fitted to external reality nor as a consensus established by a group. Basically, truth is a process of making a particular set of statements or discourses which start from the event and, from that starting point, follows from it. In short, the event precedes truth. The setting off is important since it signals a break from the continuity created by that singular event. Moreover, the event creates a new possibility, and inaugurates a new situation. In effect, the event alters the state of affairs. The truth comes after the event, thus, a truth is always the truth of the event that brings about a new situation. The conversion experience of Paul is a truth of that particular encounter. It is a subjective truth experienced by Paul who is summoned to start off a new mission. This truth cannot be captured by the state of affairs or the regime of knowledge that defines or confines the event to a repetition or reproduction of the same. Badiou usually uses the phrase "truth procedure" to drive his point that truth does not descend from above, or emanate from below. Truth is an ongoing practice and struggle. The event creates truth, and this truth is a procedure because it is an ongoing creation of the new situation. However, this truth procedure is not reducible to this process or its outcome. Truth always exceeds or surpasses the process or outcome because it continuously provides a driving force or desire that unfolds in history. For Badiou, Paul's experience of that singular event of the risen Jesus should be described as procedure rather than as content. The subjective "event" is an impetus for his persistence in the creation of a new community continuing and expanding into universalism.

Moreover, truth is intimately connected with agency. Truth is not about contemplation or discernment but about intervention or resistance in the world. One does not simply know or learn a truth; one performs it as an agent or actor that changes the status. For Badiou, the community of believers is creating a new truth of inclusion or universality, where Jews and Greeks are no longer divided, but respected. This community is an agent of change 
for inclusion and transformation. Moreover, this agency is always a collective effort, not individual endeavor. Although this is a collective endeavor, agency is not confined to a particular group having shared characteristics, such as the Jews or the Greeks, but transforms the community into an inclusive or universal openness to differences of the believers. Badiou insists that truth is not possessed by any particular group, status, and privilege but rather, shared by the whole community. This universalism is indifferent to the differences of people.

\section{Subject of Truth}

The subject does not refer to any individual or all social actors, but rather, refers to the actor who acts on the event. The subject does not align with the existing state or status, but radically alters the old order and creates a new situation. To effect change, the subject intervenes in the world. Thus, the subject effectuates a break or cut, and inaugurates or broaches a new situation. ${ }^{15}$ As a caveat, Badiou does not define the actor as a cause, but rather as the effect of an event. The subject can only exist after making a critical decision; the subject is produced through this decisive action. The subject does not choose a truth but rather truth creates the subject. The subject does not precede a truth but is constituted or produced by the truth. Thus, the subject "stands as evidence of the presence of something new in the situation." 16 In the case of Paul, the Damascus event produces a truth that compels him to decide and to act accordingly.

According to Badiou, Paul demonstrates the challenge to politics and the critique of the law. Badiou connects the making of the subject, and the questioning of the law. The subject is constituted no longer by the law, but by faith. Thus, faith is characterized by freedom from the law. Unbounded from the law, faith exceeds or surpasses the law. Gentiles are no longer in anyway different from the Jews because the Christ or Messiah is not just exclusively possessed by the Jews but given to the whole community who professes the faith in the risen Jesus. Thus, Badiou disconnects the subject and the law and connects the subject and faith. ${ }^{17}$ In his Letter to the Galatians, Paul asserts:

We ourselves are Jews by birth and not Gentile sinners; yet we know that a person is justified not by the works of the law but through faith in Jesus Christ. And

\footnotetext{
${ }^{15}$ Bruno Besana, "The Subject," in Alain Badiou: Key Concepts, eds. A.J. Barlett \& Justin Clemens (Durham: Acumen, 2010), 40.

${ }^{16}$ Pluth, A Philosophy of the New, 104.

${ }_{17}$ Stanislas Breton, A Radical Philosophy of Saint Paul (New York: Columbia University Press, 2011), 92-93.
} 
we have come to believe in Christ Jesus, so that we might be justified by faith in Christ, and not by doing the works of the law, because no one will be justified by the works of the law (Gal. 2:15-16 NRSV).

In this new order, the subject is no longer enslaved by the law that perpetuates the status or repeats the same, but freed from the law because the subject is inspired by faith in the risen Jesus. It is no longer law that rules but faith in Jesus Christ. It is no longer obedience to the law that matters, but faith in the risen Jesus. By the event of the resurrection, the subject is driven by faith that justifies; not the law that enslaves. The event of the resurrection produces a truth that the subject lives on to create a new situation. The truth unfolds in the process and creates new situation. The event calls a subject to a militant or activist vocation. That event demands fidelity of the subject. This fidelity is not an automatic repetition of the same but radical transformation of the order of things or the things as usual. The event calls for the creation of new situation. The decision made is not derived from the state or status but based only in faithfulness rooted in the event. The subject keeps on exploring the possibilities of the event; the possibilities are infinite or numerous. The subject does this exploration by mapping a new element in the situation, and by taking elements from different parts of the situation and forming them into a new set.

Moreover, the event requires persistence in the quest for truth. Badiou demands that a subject keeps on moving, regardless of the consequences involved in that action. However, this is not simply a matter of following one's own path, but a decision compelling one's own faith in pursuing a new path. The subject has to take the risks and stakes life. A subject must be indifferent to what others think around him and clings on to the event leading him/her to try a new trail. Thus, the subject is a revolutionary actor in the sense that it is consumed by the event that propels him/her to intervene in the world or resist the regime of things. An event has to create a new language for a new situation. New words must be invented, employed, and expressed beyond or outside the usual order. This new language is not prearranged or ready-made but an ordeal in the search for language. It is through a truth procedure that this new language is elaborated and specified in the process.

A truth procedure must be read on its own terms, not on other criteria derived from the past or given by a group. A truth procedure is a process based on the singularity of the event, and not on the hegemony of knowledge. It unfolds in an unpredictable manner, depending on the commitment and the movement of its subjects who pursue the truth of the event. The procedure concludes with a transformation of the state into a new situation. The 
situation is redefined in view of the truth envisioned by the subject. The entire state has to be rearranged to make room for the formerly excluded part to be included into the new set. Reality must be transformed by the subject that creates a new situation using new language. New language is created for defining the situation.

\section{Universalism in the Community}

Truth, as we have seen, is open to the possibility of universalism. Paul exemplifies that possibility of universalism when he insists on the universalizing message of the resurrection to the people by freeing the community from the rigid enclosure of Judaism (cultural privileges), and conformity to the Roman law (political and legal strictures), and the philosophy of Greece (logic and rationality). Universalism is a process of openness unfastened by the event of the resurrection that alters the existing regime of division and hierarchy. To create something universal is to go beyond the existing order or norm. The event unfolds a new situation based on the truth of the event. Paul offers a new situation in the community that breaks from the previous setup. The community envisioned by Paul is a militant singularity inspired by the event of the resurrection, and operating under a radical universalism.

Paul is aware of the composition of the community. However, the new truth exceeds the evident difference that exists between these ethnic groups. We can only receive a new truth by going beyond such differences. This new situation does not mean that the people need to renounce their customs and practices. Instead, they become indifferent to the differences of one another so that they can build a new creation or new humanity. With this in mind, Paul seeks to reorient the members, not in relation to cultural specificities (ethnicity, status or gender), but in relation to truth. The Letter to the Ephesians spells it out:

But now in Christ Jesus you who once were far off have been brought near by the blood of Christ. For he is our peace; in his flesh he has made both groups into one and has broken down the dividing wall, that is, the hostility between us. He has abolished the law with its commandments and ordinances, that he might create in himself one new humanity in place of the two, thus making peace, and might reconcile both groups to God in one body through the cross, thus putting to death that hostility through it (Eph. 2:13-16 NRSV). 
Paul is persistent with his vision of the Kingdom of God which demands fidelity to the Gospel. This vision encompasses the inclusive community where the division that separates the Jews and the Gentiles disappear and where accord among the members prevails. Thus, the community is characterized by harmony and reconciliation - not by hostility and conflict-guided by their faith in the risen Jesus. The resurrection has freed them from the bondage of the law and the faith in the risen Jesus provides freedom to the community. The law of the Jews inscribed in the Mosaic order is no longer binding but only the faith given by the grace of God rules the new humanity in the Kingdom of God. ${ }^{18}$

For Badiou, "something is universal if it is something that is beyond established differences [and] that these differences become indifferent." 19 Thus, universalism is a creation of the event whose truth is open to prospective members who believe in the risen Jesus. Faith matters in the emerging community. "Universalism is always the result of a great process that opens with an event. To create something universal is to go beyond evident differences and separations." 20 With this new truth, the community becomes indifferent to these differences. The Gospel brings about universalism where believers or followers participate in its realization. The resurrection is a singular event that proclaims the universalism of the community since it rejects the restrictions of the law or culture. Thus, Badiou refuses to follow the regimes of Jews and the Greeks in favor of universalism by becoming indifferent to differences of people.

\section{Problematic (In)Difference}

Badiou criticizes the philosophers of difference such as Emmanuel Levinas and Jacques Derrida because they recognize the difference or defend the alterity of the other. ${ }^{21}$ In that affirmation, the other essentially retains inequality or hierarchy since the other is given the upper hand in its relationship with the self. This inequality is understandable since the other has been historically wronged or oppressed by the self. These differences cannot be abrogated but must be recognized-such as sexual difference, ethnic difference, and colonial difference of peoples-because they interrogate the power that marginalizes or excludes them from society. The

\footnotetext{
18 Timothy G. Gombis, Paul: A Guide to the Perplexed (London: Bloomsbury, 2010), 133 145.

${ }^{19}$ Miller and Badiou, "Universal Truths and the Question of Religion: An Interview with Alain Badiou."

${ }^{20}$ Ibid.

${ }^{21}$ See Emmanuel Levinas, Outside the Subject, trans. by Michael Smith (California: Stanford University Press, 1994) and Jacques Derrida, The Gift of Death, trans. by David Wills (Chicago: Chicago University Press, 1995).

(C) 2020 Delfo C. Canceran

https://www.kritike.org/journal/issue 27/canceran december2020.pdf

ISSN 1908-7330
}

(c) $)$ BY-NC-ND 
hegemonic power suppressed or repressed these differences so that they are hidden and pushed. These differences will always remain such that the other will continually hunt the self to account for these atrocities.

Badiou opts for the indifference to differences because of his overarching insistence on equality and inclusion of the people in the community, regardless of their differences in class, ethnicity, and gender, to name just a few. The community should accept individuals who profess faith in the risen Jesus and not on his/her ethnicity, gender, and class. Thus, some questions occur: What shall we do with these different marks of people who belong to the community? Do we just ignore them or do we need to address them, not just for the sake of inclusion or equality but also for the sake of justice and right? In that universal unity of the people, the differences are compromised. However, a compromise only temporarily hides the disagreement and inhibits the hostility that exists between two opposing groups. Moreover, tolerance implies that the dominant group allows a practice or action within their own standards. When those limits are transgressed, the dominant group will impose restraints to the unruly subordinate group. ${ }^{22}$

In particular, Derrida speaks about justice in contrast to the law. While the law is general in its application by treating the cases in the same way (The law applies to all), justice is singular in its application to different cases of people. Thus, the law highlights the generality of the same, and justice emphasizes the singularity of the other. The law relies on past decisions and applies to similar cases, while justice considers the past and the present. In the singularity of the other, the judge undergoes the ordeals of decision by detailing the situation of the other. There is always the irreducibility of the new situation different from the old situation. In effect, the decision blends the old and the new in the singularity of the other. The singularity of the other applies to woman in sexual differences, to colonies in racial discrimination, to blacks in racism, to gays in heterosexism, to migrants in globalization. The point of justice is to highlight the marginalization and exclusion of the other, and the interrogation and transformation of the situation. The democracy to come is the breaking of the same, and the opening of the space for the unexpected other, undefined by the past and even by the present. The other is always to come. ${ }^{23}$

The social teaching of the Church insists on the preferential love or option for the poor since, historically and politically, they have been deprived

\footnotetext{
22 See Steve Clarke, Russell Powell \& Julian Savulescu, Religion, Intolerance and Conflict: A Scientific and Conceptual Investigation (Oxford: Oxford University Press, 2013).

${ }^{23}$ Jacques Derrida, "Force of Law: The 'Mystical Foundation of Authority,'” trans. by Mary Quaintance in Cardozo Law Review, 11:5-6 (1990).
} 
by society and subordinated to the elite. That unjust status should be rectified , and addressed. The option for the poor is a commitment that demands social justice so that the poor can also benefit from the creation of God, and enjoy their lives in the community. There is no peace without justice. Peace is not just the negation of violence, but the positivity of life that endeavors for happiness and fulfillment. We need to address the social problems of people, and rectify injustices so that we create a just society, and benefit from the bounty of the earth. Thus, we need to be inclusive and fair but, as a requirement, we need social justice for those who have been dispossessed of the fullness of life since they suffer from dearth and bigotry. Thus, the priority is the building of the Church of the poor based on the imperative of the justice and the flourishing of life.

\section{Conclusion}

Paul's encounter with the risen Jesus on the road to Damascus transformed his identity and propelled his proclamation of this singular event. Badiou claims that Paul recognizes that the resurrection of Jesus Christ is not pointing to some Jewish sign or Greek wisdom that could be bound to a particular group or fixed to a particular culture. That encounter is a singular and pure event, devoid of such exclusivities or particularities, and opens the path to universalism and equality. The event is indifferent to the differences of people because it is not tied to any group, and not restricted by any law; it is open to everyone willing to embrace that event and to perform the truth. This event is transformative because it inspires the subject to become a new creation or new humanity rooted in the resurrection. Paul is an apostle of revolutionary project where he forms community as a militant collection or multitude of subjects operating under an avant-garde movement toward a radical universalism. However, a problem arises on the minimalization of differences and the maximization of similarities of the people in view of inclusion and equality in the community which may undermine the struggles of the others who have suffered from discriminations and injustices.

Ecclesiastical Faculties, University of Santo Tomas, Philippines

\section{References}

Badiou, Alain, Saint Paul: The Foundation of Universalism, trans. by Ray Brassier, (Stanford: Stanford University Press, 2003).

The Rebirth of History: Times of Riots and Uprisings, trans. by Gregory Elliott (London: Verso, 2012).

(c) 2020 Delfo C. Canceran

https://www.kritike.org/journal/issue 27/canceran december2020.pdf

ISSN 1908-7330

(cc) BY-NC-ND 
Besana, Bruno, "The Subject," in Alain Badiou: Key Concepts, ed. by A.J. Barlett \& Justin Clemens (Durham: Acumen, 2010).

Boyarin, Daniel, A Radical Jew: Paul and the Politics of Identity (Berkley: University of California Press, 1994).

Breton, Stanislas, A Radical Philosophy of Saint Paul (New York: Columbia University Press, 2011).

Clarke, Steve, Russell Powell \& Julian Savulescu, Religion, Intolerance and Conflict: A Scientific and Conceptual Investigation (Oxford: Oxford University Press, 2013).

Derrida, Jacques, "Force of Law: The 'Mystical Foundation of Authority,'” trans. by Mary Quaintance, in Cardozo Law Review, 11:5-6, (1990).

The Gift of Death, trans. by David Wills (Chicago: Chicago University Press, 1995).

Hacker, Klaus, "Paul's Life," in The Cambridge Companion to Saint Paul, ed. by James D.G Dunn (Cambridge: Cambridge University Press, 2003).

Kuhn, Thomas, The Structure of Scientific Revolution (Chicago: Chicago University Press, 1962).

Levinas, Emmanuel, Outside the Subject, trans. by Michael Smith (California: Stanford University Press, 1994).

Miller, Adam and Alain Badiou, "Universal Truths and the Question of Religion: An Interview with Alain Badiou," in Journal of Philosophy and Scripture, 3:1 (2005).

Murphy-O'Connor, Jerome, Paul: His Story (Oxford: Oxford University Press, 2004).

Norris, Christopher, Badiou's Being and Event (London: Continuum, 2009).

Pluth, Ed, Badiou: A Philosophy of the New, (Cambridge: Polity Press, 2010).

Porter, Stanley, "Paul as Jew, Greek and Roman: An Introduction," in Paul: Jew, Greek and Roman, ed. by Stanley E. Porter (Leiden: Brill, 2008).

Timothy Gombis, Paul: A Guide to the Perplexed (London: Bloomsbury, 2010).

Wallace, Richard, and Wynne Williams, The Three Worlds of Paul of Tarsus, (London: Routledge, 1998).

Wright, N.T, What Saint Paul Really Said: Was Paul of Tarsus the Real Founder of Christianity?, (Michigan: William B. Eerdmans Publishing Company, 1997). 